\title{
Negative effects of gardening damselfish Stegastes planifrons on coral health depend on predator abundance
}

\author{
M. J. A. Vermeij ${ }^{1,2, *}$, H. DeBey ${ }^{3}$, G. Grimsditch ${ }^{4}$, J. Brown ${ }^{5}$, D. Obura ${ }^{6}$, R. DeLeon ${ }^{7}$ \\ S. A. Sandin ${ }^{8}$ \\ ${ }^{1}$ Carmabi Foundation, Piscaderabaai z/n, PO Box 2090, Willemstad, Curaçao \\ ${ }^{2}$ Aquatic Microbiology, Institute for Biodiversity and Ecosystem Dynamics (IBED) University of Amsterdam, \\ Science Park 700, 1098 XH, Amsterdam, the Netherlands \\ ${ }^{3}$ National Marine Fisheries Service, Silver Spring, Maryland 20910, USA \\ ${ }^{4}$ United Nations Environment Program, Nairobi, PO Box 30552-00100, Kenya \\ ${ }^{5}$ The Nature Conservancy, 3052 Estate Little Princess, Christiansted, US Virgin Islands 00820 \\ ${ }^{6}$ CORDIO East Africa, Bamburi Beach, PO Box 10135, Mombasa 80101, Kenya \\ ${ }^{7}$ Bonaire National Marine Park, Barcadera z/n, Kralendijk, Bonaire, Dutch Caribbean \\ ${ }^{8}$ Center for Marine Biodiversity and Conservation, Scripps Institution of Oceanography, \\ University of California at San Diego, La Jolla, California 92037, USA
}

\begin{abstract}
On Bonaire, we studied the effects of predator abundance and habitat availability on the abundance of the threespot damselfish Stegastes planifrons, a species that creates algal gardens at the expense of live coral cover. Across 21 sites, predator biomass ranged from 12 to $193 \mathrm{~g} \mathrm{~m}^{-2}$ (mean $=55.1 ; \mathrm{SD}=49.1$ ) and benthic cover of $S$. planifrons' preferred habitat (corals of the Orbicella species complex) ranged from 2.2 to $38.0 \%$ (mean $=14.3 ; \mathrm{SD}=9.6$ ). Across these gradients, the local abundance of $S$. planifrons was significantly and negatively related to predator biomass, but not to habitat availability. Increased local abundance of $S$. planifrons corresponded to an increasingly larger proportion of coral colonies affected by its 'farming behavior', resulting in an increased prevalence of coral disease. Thus, predators indirectly affected the composition of reef communities around Bonaire by controlling damselfish abundance. Furthermore, the abundance of $S$. planifrons could not be correlated with its preferred habitat, despite such correlations having been observed elsewhere in the Caribbean.
\end{abstract}

KEY WORDS: Stegastes planifrons $\cdot$ Bonaire $\cdot$ MPA $\cdot$ Prey release $\cdot$ Damselfish $\cdot$ Orbicella spp.

\section{INTRODUCTION}

The reduction in fish stocks is one of the most notable changes on Caribbean reefs over the last decades (Jackson et al. 2001, Pandolfi et al. 2003), and marine fishes that otherwise influence community structure over vast areas, such as herbivorous fish and large predatory fish, are no longer abundant enough to fulfill such ecological functions. After predatory fish have declined in abundance through overfishing, their prey, such as fish species untargeted by fishermen, often increase in number as these prey species become relieved of historically experienced predator-induced mortality rates of $90 \%$ or more (e.g. Shulman \& Ogden 1987, Hixon \& Carr 1997). The decline in abundance of predators can 
affect the integrity of the wider reef community when their prey species can modify their habitat in a detrimental way (Sandin et al. 2010).

The best known examples of reef organisms that increase numerically after their predators are fished out are echinoderm species capable of modifying their surrounding habitat. Examples include corallivorous starfish (Dulvy et al. 2004) and substrateeroding sea urchins (Vermeij et al. 2010). One fish species that has increased in abundance relative to historic baselines is the Caribbean threespot damselfish Stegastes planifrons Cuvier 1830 (Bruckner \& Bruckner 2003, Steneck \& McClanahan 2005). This fish historically ( $>50 \mathrm{yr}$ ago) occurred in extremely low abundances ( 0.2 to $1.2 \mathrm{~g} \mathrm{~m}^{-2}$ ) on Bonaire and Curaçao in the southern Caribbean (Collins 1956, Nagelkerken 1974), where it was considered a 'cryptic species' since it hid underneath and between branches of coral (Luckhurst \& Luckhurst 1978). Like echinoderms, S. planifrons has the ability to modify its benthic surroundings by building, maintaining and defending permanent individual territories consisting of erect algal mats. These 'gardens' are created at the expense of corals that previously occupied the same area (Hinds \& Ballantine 1987). S. planifrons aggressively defends its territory against herbivores (e.g. Williams 1980) and selectively prunes specific algal species to grow in the mat, serving as a continuous food source (Ceccarelli et al. 2001).

After overfishing drives a population of predatory fish to 'ecological extinction' (i.e. a species is reduced to such low abundance that it no longer interacts significantly with other species), local prey abundance can become dependent on other structuring processes, such as the availability of food and shelter (Dulvy et al. 2004). In Caribbean reef communities that are characterized by a low abundance of predators (between 2.3 and $22.5 \mathrm{~g} \mathrm{~m}^{-2}$ ), species-specific microhabitat preferences and the availability of topographically complex microhabitats determine the local abundance of $S$. planifrons (Precht et al. 2010). Inside well-protected marine parks, the biomass of predators is higher (approx. 10 to $200 \mathrm{~g} \mathrm{~m}^{-2}$; Newman et al. 2006), which raises the question whether the abundance of $S$. planifrons under such 'predatorheavy' conditions can still be predicted from the abundance of their preferred habitat.

Given the effects of $S$. planifrons on Caribbean reef communities (i.e. facilitating the replacement of living corals with turf algae), we aimed to elucidate the environmental factors that best predict $S$. planifrons local abundance in a relatively healthy reef system within the Bonaire National Marine Park (Grimsditch et al. 2011). On Bonaire, predators are more abundant than on many other Caribbean reefs (Precht et al. 2010). We therefore investigated whether the abundance of $S$. planifrons depended on the availability of its preferred habitat (large Orbicella corals), general benthic community characteristics or the abundance of potential predators.

\section{MATERIALS AND METHODS}

\section{Study site}

Fieldwork was conducted on the fringing reefs of Bonaire $\left(12^{\circ} \mathrm{N}, 68^{\circ} \mathrm{W}\right)$, in the southern Caribbean Sea from May to June 2009. The entire reef system has been protected as part of the Bonaire National Marine Park (BNMP) since 1979 and has been under consistent management since 1991. Despite a variety of local threats (Steneck \& McClanahan 2005, Grimsditch et al. 2011), Bonaire's coral reefs are considered to be among the healthiest in the Caribbean (Jackson et al. 2013). Fish and benthic community composition were quantified at 21 sites along the southwestern (leeward) shore of Bonaire and around the nearby island of Klein Bonaire, which is located $0.8 \mathrm{~km}$ off Bonaire's leeward shore (Fig. 1).

\section{Study organism}

The threespot damselfish Stegastes planifrons is a small territorial herbivorous damselfish that 'farms' benthic algae in a territory that it defends against roving herbivores. The species has been a part of Caribbean reef systems for at least 125000 yr, (Kaufman 1981) and while coral is a small part of its diet $(<1 \%$; Randall 1967), S. planifrons destroys living coral surfaces to establish algal gardens (Kaufman 1977, Hinds \& Ballantine 1987). Now that the species' preferred habitat (branching Acroporids) has largely disappeared from the Caribbean, S. planifrons prefers the scleractinian corals Orbicella annularis and $O$. faveolata as its primary microhabitat on shallow reefs throughout the Caribbean (Eakin 1989, Precht et al. 2010).

\section{Benthic surveys}

Cover of all major benthic groups and speciesspecific cover of stony corals (Scleractinia) and of the calcifying hydroid Millepora complanata was quanti- 


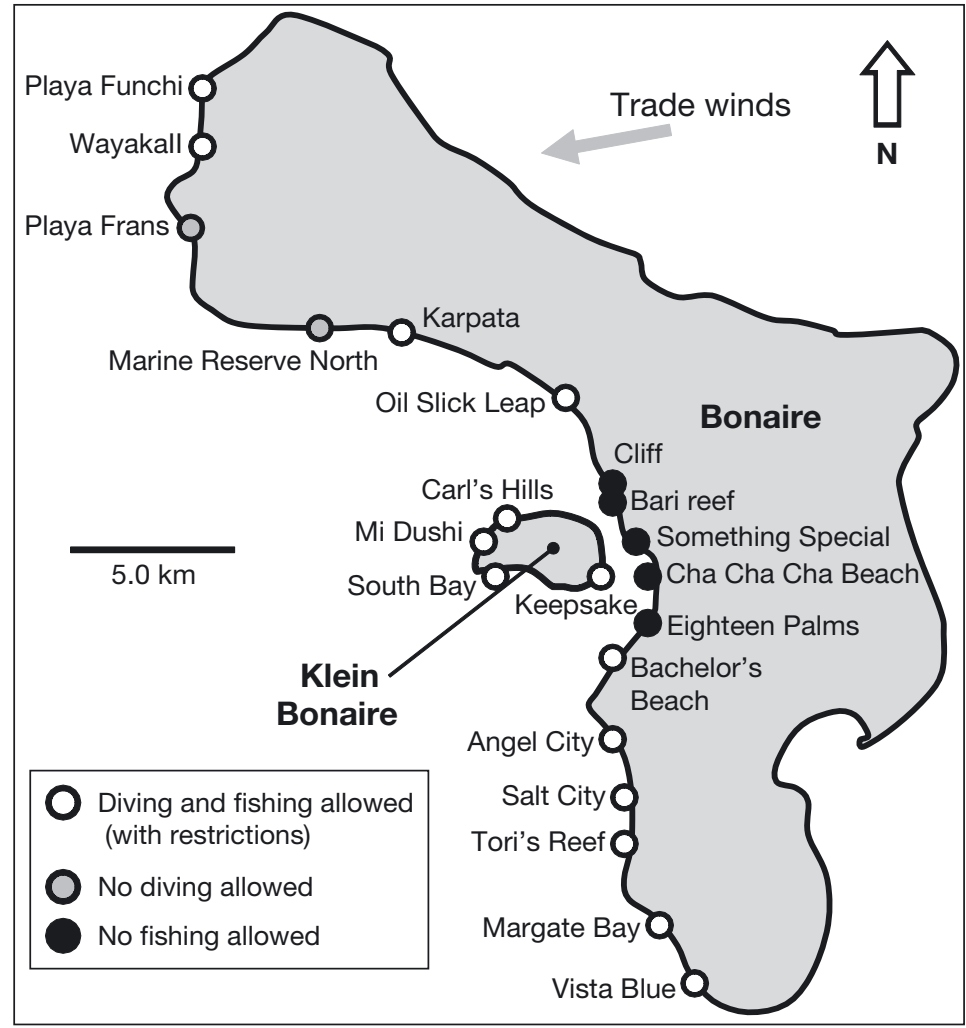

Fig. 1. Study locations on Bonaire. All study sites are on the leeward sides of the island. All sites are within the Bonaire National Marine Park (BNMP) and certain sites are additionally protected from fishing (since 2007) and diving. The area spanned by the filled black circles also correspond to the urbanized area of the island

fied at each site in three $25 \times 1 \mathrm{~m}$ belt transects that were laid out parallel to the shore between depths of 8 and $10 \mathrm{~m}$, whereby subsequent transects were separated by at least $10 \mathrm{~m}$. In each belt transect, the size and species of all corals larger than $10 \mathrm{~cm}$ in diameter were noted to generate site-specific estimates of local coral community composition. Colonies smaller than $10 \mathrm{~cm}$ were not included because of their small relative contribution to overall coral cover. When present, the presence and type of coral disease and S. planifrons territories were noted for each coral colony (for more details, see Obura \& Grimsditch 2009). All cover data were expressed as the percentage of habitable substrate occupied by each benthic group; sand and/or rubble were considered uninhabitable substrate types.

\section{Fish surveys}

Fish surveys focused on herbivore functional groups and predatory fish following the methods of
Green et al. (2009). The total length (TL) and species identity of all herbivorous and predatory fish near the benthos and in the overlying water column $(<2 \mathrm{~m})$ were recorded in up to three $30 \times 4 \mathrm{~m}$ belt transects per site. Transects were positioned near to, but not overlapping, the benthic transects, thereby allowing for concurrent sampling of the benthos without disturbance of fish behavior. Transects were laid out similarly to those used for the benthic surveys following a depth contour between 8 and $12 \mathrm{~m}$. After a new transect was laid out, fish surveys were started $5 \mathrm{~min}$ later to allow fish that might have hidden when the transect was laid to resume their normal behaviors. Surveys were completed in 5 min per transect to standardize sampling effort among transects. The fish surveys focused on 3 functional groups of fishes: (1) S. planifrons and 3 other damselfish species (S. leucostictus, S. diencaeus and Microspathodon chrysurus), (2) herbivorous fish capable of removing epilithic turf and macroalgae from the reef substratum (members of the families Scaridae, Acanthuridae, Kyphosinae), and (3) piscivorous fish (members of the families Lutjanidae, Haemulidae, Aulostomidae, Serranidae, Carangidae, Synodontidae) (Randall 1967, Froese \& Pauly 2011). Fish length was estimated to the nearest $\mathrm{cm}$ by sight and calibrated by exact measurement of nearby landmarks when needed. Accuracy of length estimates was maintained with periodic tests for the divers in situ, and observer bias was minimal as all census data was collected by the same divers. Total lengths of fish were converted into biomass estimates (in $\mathrm{g} \mathrm{m}^{-2}$ ) based on the product of species- and size-specific density estimates and species-specific weight-length relationships (available at www.fishbase.org; (Froese \& Pauly 2011). For details see Obura \& Grimsditch (2009).

\section{Statistical analyses}

Relationships among the local abundances of functional groups on Bonaire's reefs were investigated using Kendall's rank correlation making no a priori assumptions regarding the distributions of $\mathrm{X}$ or $\mathrm{Y}$ or the distribution of $(\mathrm{X}, \mathrm{Y})$. The same approach was used to determine whether predictable relationships existed between abundance of $S$. planifrons and 
number of diseased coral colonies at a site. Because the abundance of $S$. planifrons is hypothesized to be dependent on predator abundance and/or habitat availability (i.e. the abundance of Orbicella spp.; sensu Precht et al. 2010), we explicitly tested the prediction that $S$. planifrons abundance is dependent on both factors using multiple correlation. To test whether S. planifrons individuals preferred certain coral species to establish their territories, the relative abundances of all coral species were pooled at an island level across Bonaire and compared to the distribution of $S$. planifrons across the same coral species. We then assumed a random distribution of $S$. planifrons across all coral species and tested for deviations to this expected distribution using a chisquared goodness-of-fit analysis.

\section{RESULTS}

\section{Damselfish distribution}

Of all benthic and fish groups considered in this study, only the abundance of predatory fishes could be related to the local abundance of $S$. planifrons (Fig. 2a). The local biomass of predatory fish correlated significantly and negatively with the local abundance of $S$. planifrons $(\mathrm{r}=-0.46, \mathrm{p}<0.05)$. In contrast, the local abundance of $S$. planifrons did not vary in response to its preferred habitat (Orbicella spp.) (Fig. $2 b, r=0.35$ ) even when the stronger effect of predators was removed (multiple correlation; $\mathrm{r}_{\text {orbicella }}=-0.06, \mathrm{p}=0.81$ ). All possible relationships between the abundance of benthic groups and $S$. planifrons abundance were tested; apart from the above relationships, the abundance of no other benthic group (overall coral, turf and macroalgal cover) was related to the local abundance of $S$. planifrons (Table 1). The abundance of $S$. planifrons was, however, significantly and positively correlated with the proportion of local coral colonies affected by disease (Fig. 2c, r = 0.62, p < 0.01). Across Bonaire, most coral colonies with signs of disease $(n=69)$ belonged to the Orbicella species complex and suffered from yellow blotch disease (sensu Bruckner 2003). The abundance of other territorial damselfishes (Stegastes leucostictus, S. diencaeus and Microspathodon chrysurus) did not affect the abundance of $S$. planifrons $(-0.38<\mathrm{r}<-0.08, \mathrm{p}>0.09)$, suggesting a low degree of interspecific competition (sensu Robertson 1996). None of the other 3 damselfish species were affected by the abundance of predators or habitat availability like S. planifrons (multiple correlation; $\mathrm{r}_{\text {orbicella }}>-0.30$;
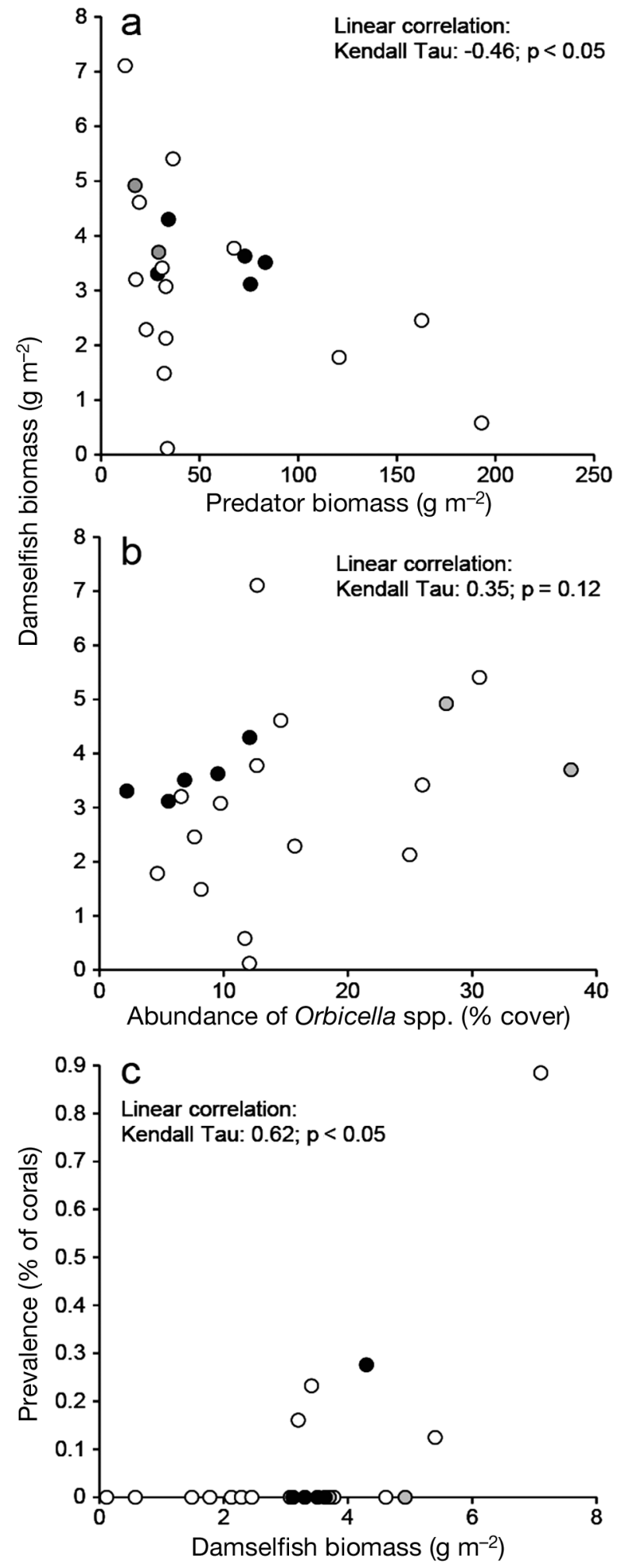

Fig. 2. Relationships between the local abundance of territorial damselfish Stegastes planifrons and (a) predatory fishes, (b) availability of preferred habitat and (c) disease prevalence at 21 sites on Bonaire. Circle color corresponds to protection status: white, diving and fishing allowed (with restrictions); grey, no diving; black, no fishing (see also Fig. 1) 
Table 1. Matrix of potential correlations (Kendall's rank) among the average abundance of benthic and fish groups considered in this study for 21 sites on Bonaire. Significant correlations $(p<0.05)$ in bold

\begin{tabular}{|lccccc|}
\hline & $\begin{array}{c}\text { Macro- } \\
\text { algae } \\
(\% \text { cover })\end{array}$ & $\begin{array}{c}\text { Turf } \\
\text { algae } \\
(\% \text { cover })\end{array}$ & $\begin{array}{c}\text { Diseased } \\
\text { coral } \\
(\%)\end{array}$ & $\begin{array}{c}\text { Predatory } \\
\text { fish } \\
\left(\mathrm{g} \mathrm{m}^{-2}\right)\end{array}$ & $\begin{array}{c}\text { Damselfish } \\
\left(\mathrm{g} \mathrm{m}^{-2}\right)\end{array}$ \\
\hline Coral (\% cover) & $\mathbf{- 0 . 4 9}$ & 0.26 & 0.04 & -0.39 & 0.35 \\
Macroalgae & & -0.06 & -0.15 & 0.22 & -0.23 \\
Turf algae & & & 0.65 & -0.30 & 0.50 \\
Diseased coral & & & & -0.29 & $\mathbf{0 . 6 2}$ \\
Predatory fish & & & & & $\mathbf{- 0 . 4 6}$ \\
\hline
\end{tabular}

$\left.\mathrm{p}>0.20 ; \mathrm{r}_{\text {predators }}>-0.44 ; \mathrm{p}>0.06\right)$, except for the yellowtail damselfish, whose abundance was positively correlated with the local abundance of Orbicella colonies $\left(\mathrm{r}_{\text {orbicella }}=0.586 ; \mathrm{p}=0.01\right)$.

\section{Damselfish habitat preference}

Territories of the damselfish were observed on colonies of 12 different coral species (Fig. 3a). S. planifrons did occur in greater densities than expected from a random distribution on 4 massive coral species: Orbicella annularis (2.6× higher), O. faveolata (3.9× higher), O. franksi (3.6× higher) and Colpophylia natans $(1.2 \times$ higher) (chi-square $=$ 176.24, df $=16$, p < 0.01). S. planifrons apparently prefers large, massive coral species over small, branching and structurally more complex species such as Eusmilia fastigiata, Millepora complanata, Madracis decactis and M. mirabilis (Fig. 3b).

\section{DISCUSSION}

Abundance of Stegastes planifrons correlated negatively with the abundance of predators on Bonaire's reefs (Fig. 2a), suggesting that within the context of the Bonaire National Marine Park, predatory fish represented a stronger controlling factor on S. planifrons abundance (through direct consumption, sensu Paine 1980) than the abundance of its preferred habitat, namely corals of the Orbicella species complex (Figs. 2b \& 3b; Precht et al. 2010). Precht et al. (2010) found the opposite pattern when looking at the relationship between predators, habitat availability and the local abundance of $S$. planifrons across 5 Caribbean locations (Florida, the Bahamas, Jamaica, Cayman Islands and Belize) where habitat availability rather than predator abundance best predicted the local abundance of $S$. planifrons. However, those observations and the ones presented here are not mutually exclusive.

Bonaire ranks highest in terms of biomass of predatory fishes of all the locations covered in both studies (Fig. 4). When populations of predators are reduced or extinct, previously suppressed prey populations, such as those of $S$. planifrons, can increase in size (Rayner et al. 2007), and local resources such as food or shelter become more important in determining their local abundance (e.g. Crowder \& Cooper 1982, Sandin et al. 2008). McClanahan (2005) also observed that predatory fish reduced the number of damselfish in Belize, the site with the next highest abundance of predators considered here (Fig. 4). Combined with our data and those of Precht et al. (2010), this suggests that $S$. planifrons abundance is regulated by predators when such predators are abundant (for example on Bonaire and Belize), and
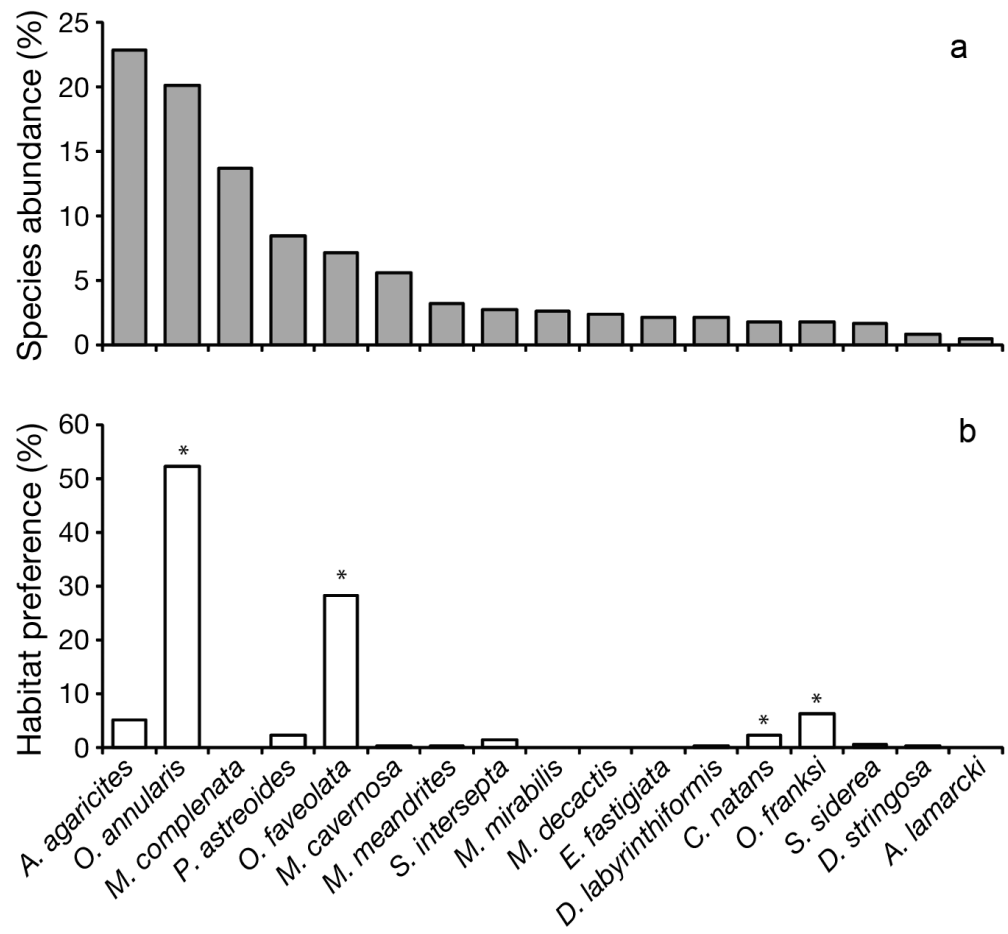

Fig. 3. (a) Relative abundance of the 17 most abundant coral species on Bonaire. (b) Distribution of Stegastes planifrons across the most common coral species. * Significantly preferred by $S$. planifrons 
by resources such as habitat availability when predators are rare. The data presented here in combination with those of Precht et al. (2010) strongly suggest the existence of a 'switch' whereby the relative importance of one controlling factor of $S$. planifrons abundance (habitat availability) overtakes another (predator abundance) as predator abundance decreases locally.

Because territorial damselfish such as $S$. planifrons actively promote algal growth within their territories, often at the cost of living coral, their increased abundance comes with consequences for the reef communities in which they occur. $S$. planifrons creates 'algal territories' from which it feeds on algae and small animals (Randall 1967, Dromard et al. 2013), but rather than depleting this food source, it actively maintains and expands it. In some cases, S. planifrons must kill live coral tissue to create space for its territory, but does not feed on coral tissue in significant amounts (Randall 1967). Because S. planifrons defends its territory against herbivorous fish and urchins, it further reduces local levels of herbivory, accelerating the local rate of algal proliferation (Williams 1980, Precht et al. 2010). Thus, the effect of S. planifrons on benthic community composition is largely mediated through its own behavior (making

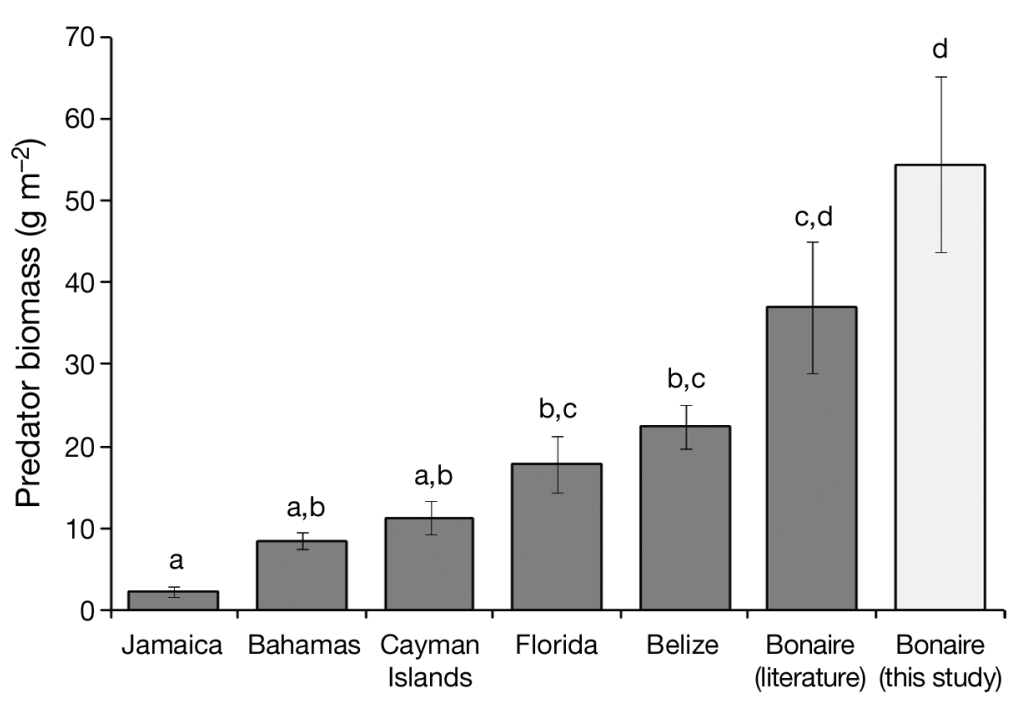

Fig. 4. The abundance of predatory fishes (members of the families Lutjanidae, Haemulidae, Aulostomidae, Serranidae, Carangidae, and Synodontidae) for all locations considered in this study (Bonaire) and in Precht et al. (2010). White bar, this study; grey bars, previously published data Jamaica: 74 sites (Newman et al. 2006, Marks \& Lang 2007); Bahamas: 26 sites (Marks \& Lang 2007); Cayman Islands: 34 sites (Marks \& Lang 2007); Florida: 28 sites (Newman et al. 2006, Marks \& Lang 2007); Belize: 8 sites (Newman et al. 2006); Bonaire: 10 sites (Marks \& Lang 2007, Sandin et al. 2007). Error bars represent standard error; letters above the bars indicate significant differences $(\mathrm{p}<0.05)$ based on ANOVA followed by post-hoc tests (Tukey) territories) or by changing the behavior of other ecosystem engineers (chasing away herbivorous fish and sea urchins). Besides the direct negative effect of their gardening behavior on coral cover, increased damselfish abundance is also positively correlated with the occurrence of diseased coral colonies (Casey et al. 2014). Coral disease is associated with increased (turf) algal cover inside the damselfish territories (e.g. Harvell et al. 2004, Casey et al. 2014) and coral disease and disease-like symptoms may be induced or mediated by bacteria harbored on or fueled by neighboring algae (Nugues et al. 2004, Smith et al. 2006).

Algae represent only a quarter of $S$. planifrons' diet (Randall 1967) and algal abundance increases more due to $S$. planifrons' 'farming behavior' than it decreases through $S$. planifrons' consumption of algae. The foremost effect of increased $S$. planifrons abundance on lower trophic levels (primary producers) is thus behavioral; such predator-prey interactions are commonly referred to as 'trait-mediated indirect interactions' (Stallings 2008). Qualifying the dynamic discussed here (i.e. fewer predators $\rightarrow$ more damselfish $\rightarrow$ more algae) as a trophic cascade across 3 trophic levels (Sandin et al. 2010) would be inaccurate given the missing trophic link between the abundance of damselfish and (turf) algae. The dynamic is better regarded as an example of 'prey release' between 2 trophic levels (predators and S. planifrons), confirming similar findings from Australian and Pacific reefs (Ceccarelli et al. 2006). The lower abundance of predators has indirect effects on lower trophic levels (i.e. increased abundance of primary producers), but this effect is largely behaviorally mediated as $S$. planifrons farms, rather than consumes, benthic algae and chases away reef herbivores.

We propose that the structuring influence of predatory fish on the abundance of $S$. planifrons disappears when predator abundance falls below $\sim 40 \mathrm{~g} \mathrm{~m}^{-2}$. $S$. planifrons' destructive behavior (with respect to the corals) is comparable to the destructive behavior of other organisms (mostly echinoderms) that are increasing in abundance on present-day reefs that have seen the large-scale removal of the predators of such species. Because our findings are solely based on observations made on Bonaire, our con- 
clusions should be experimentally tested, for example by using changes in the protection status of certain sites (from open to no-take or vice versa) in a BACI (before-after, control-impact) design. The fact that altered trophic interactions within reef communities are primarily documented through the increased abundance and activity of obviously destructive species (such as bioeroding sea urchins, corallivorous starfish and algal-farming damselfish) makes one wonder how many subtle changes in reef trophic dynamics remain presently unnoticed.

Acknowledgements. We thank Kristen Marhaver for making textual improvements in the manuscript.

\section{LITERATURE CITED}

Bruckner AW, Bruckner RJ (2003) Condition of coral reefs off less developed coastlines of Curacao (Part 2: Reef fishes). Atoll Res Bull 496:394-403

Casey JM, Ainsworth TD, Choat JH, Connolly SR (2014) Farming behaviour of reef fishes increases the prevalence of coral disease associated microbes and black band disease. Proc R Soc B 281:20141032

Ceccarelli DM, Jones GP, McCook LJ (2001) Territorial damselfishes as determinants of the structure of benthic communities on coral reefs. Oceanogr Mar Biol Annu Rev 39:355-389

> Ceccarelli DM, Hughes TP, McCook LJ (2006) Impacts of simulated overfishing on the territoriality of coral reef damselfish. Mar Ecol Prog Ser 309:255-256

Collins HH (1956) Birds and fish of the Netherlands Antilles. Caribou Press, Bronxville, NY

> Crowder LB, Cooper WE (1982) Habitat structural complexity and the interaction between bluegills and their prey. Ecology 63:1802-1813

> Dromard CR, Bouchon-Navaro Y, Cordonnier S, Fontaine MF, Verlaque M, Harmelin-Vivien M, Bouchon C (2013) Resource use of two damselfishes Stegastes planifrons and Stegastes adustus, on Guadeloupean reefs (Lesser Antilles): inference from stomach content and stable isotope analysis. J Exp Mar Biol Ecol 440:116-125

Dulvy NK, Freckleton RP, Polunin NV (2004) Coral reef cascades and the indirect effects of predator removal by exploitation. Ecol Lett 7:410-416

Eakin CM (1989) Microhabitat selection in juveniles of the damselfishes Pomacentrus planifrons and P. partitus. Proc Assoc Isl Mar Lab Caribb 22:35-36

Froese R, Pauly D (2011) FishBase 2011. Available at: www.fishbase.org (accessed on 22 February 2011)

Green AL, Bellwood DR, Choat H (2009) Monitoring functional groups of herbivorous reef fishes as indicators of coral reef resilience. A practical guide for coral reef managers in the Asia Pacific Region. IUCN, Gland. Available at: http://cmsdata.iucn.org/downloads/resilience_ herbivorous_monitoring.pdf

Grimsditch G, Arnold S, de Bey H, Brown J, Engel S, de Leon R, Vermeij M (2011) Coral reef resilience assessment of the Bonaire National Marine Park, Netherlands Antilles. IUCN, Gland

Harvell D, Aronson R, Baron N, Connell J and others (2004)
The rising tide of ocean diseases: unsolved problems and research priorities. Front Ecol Environ 2:375-382

Hinds PA, Ballantine DL (1987) Effects of the Caribbean threespot damselfish, Stegastes planifrons (Cuvier), on algal lawn composition. Aquat Bot 27:299-308

Hixon MA, Carr MH (1997) Synergistic predation, density dependence, and population regulation in marine fish. Science 277:946-949

Jackson JB, Kirby MX, Berger WH, Bjorndal KA and others (2001) Historical overfishing and the recent collapse of coastal ecosystems. Science 293:629-637

Jackson J, Donovan MK, Cramer K, Lam Y (2013) Status and trends of Caribbean coral reefs: 1970-2012. Global Coral Reef Monitoring Network, IUCN, Gland

Kaufman L (1977) The 3-spot damselfish: effects on the benthic biota of Caribbean reefs. Proc 3rd Int Coral Reef Symp, Miami, FL, 1:559-564

Kaufman L (1981) There was biological disturbance on Pleistocene coral reefs. Paleobiology 7:527-532

> Luckhurst B, Luckhurst K (1978) Analysis of the influence of substrate variables on coral reef fish communities. Mar Biol 49:317-323

Marks KW, Lang JC (2007) AGRRA Summary Products, version (10/2007). Available at: www.agrra.org/Release 2007-10

McClanahan T (2005) Recovery of carnivores, trophic cascades, and diversity in coral reef marine parks. Large carnivores and the conservation of biodiversity. Island Press, Washington, DC, p 247-267

Nagelkerken W (1974) On the occurrence of fishes in relation to corals in Curaçao. Caribbean Marine Biological Institute, Willemstad

Newman MJ, Paredes GA, Sala E, Jackson JB (2006) Structure of Caribbean coral reef communities across a large gradient of fish biomass. Ecol Lett 9:1216-1227

Nugues MM, Smith GW, Hooidonk RJ, Seabra MI, Bak RP (2004) Algal contact as a trigger for coral disease. Ecol Lett 7:919-923

Obura D, Grimsditch G (2009) Resilience assessment of coral reefs: assessment protocol for coral reefs, focusing on coral bleaching and thermal stress. IUCN, Gland

Paine RT (1980) Food webs: linkage, interaction strength, and community infrastructure. J Anim Ecol 49:667-685

Pandolfi JM, Bradbury RH, Sala E, Hughes TP and others (2003) Global trajectories of the long-term decline of coral reef ecosystems. Science 301:955-958

Precht WF, Aronson RB, Moody RM, Kaufman L (2010) Changing patterns of microhabitat utilization by the threespot damselfish, Stegastes planifrons, on Caribbean reefs. PLoS ONE 5:e10835

Randall JE (1967) Food habits of reef fishes of the West Indies. Institute of Marine Sciences, University of Miami, FL

Rayner MJ, Hauber ME, Imber MJ, Stamp RK, Clout MN (2007) Spatial heterogeneity of mesopredator release within an oceanic island system. Proc Natl Acad Sci USA 104:20862-20865

Robertson DR (1996) Interspecific competition controls abundance and habitat use of territorial Caribbean damselfishes. Ecology 77:885-899

Sandin SA, Sampayo EM, Vermeij MJA (2007) Coral reef fish and benthic community structure of Bonaire and Curaçao, Netherlands Antilles. Caribb J Sci 44:137-144

Sandin SA, Smith JE, DeMartini EE, Dinsdale EA and others (2008) Baselines and degradation of coral reefs in the 
northern Line Islands. PLoS One 3:e1548

Sandin SA, Walsh SM, Jackson JBC (2010) Prey release, trophic cascades, and phase shifts in tropical nearshore ecosystems. In: Terborgh J, Estes JA (eds) Trophic cascades: predators, prey, and the changing dynamics of nature. Island Press, Washington, DC, p 71-90

Shulman M, Ogden J (1987) What controls tropical reef fish populations: recruitment or benthic mortality? An example in the Caribbean reef fish Haemulon flavolineatum. Mar Ecol Prog Ser 39:233-242

Smith JE, Shaw M, Edwards RA, Obura D and others (2006) Indirect effects of algae on coral: algae-mediated, microbe-induced coral mortality. Ecol Lett 9:835-845

Editorial responsibility: Janet Ley, St. Petersburg, Florida, USA
Stallings CD (2008) Indirect effects of an exploited predator on recruitment of coral-reef fishes. Ecology 89:2090-2095

Steneck RS, McClanahan T (2005) A report on the status of the coral reefs of Bonaire in 2005 with advice on a monitoring program. Unpublished report to the Bonaire Marine National Park (STINAPA): University of Maine Darling Marine Center

Vermeij MJA, Dailer ML, Walsh SM, Donovan MK, Smith CM (2010) The effects of trophic interactions and spatial competition on algal community composition on Hawaiian coral reefs. Mar Ecol 31:291-299

Williams AH (1980) The threespot damselfish: a noncarnivorous keystone species. Am Nat 116:138-142

Submitted: November 10, 2014; Accepted: February 16, 2015 Proofs received from author(s): May 14, 2015 